NGTT Deel 54, Nommers 3 \& 4, September en Desember 2013

Rasmusson, Arne ${ }^{1}$

Umeå University, Sweden

Stellenbosch University

\title{
Church and war in the theology of Karl Barth
}

\begin{abstract}
The issues around church and war followed Karl Barth during his whole career. His most extensive and systematic discussions of war are found in the Church Dogmatics. Here he questions the naturalness of war and develops a theologically motivated understanding of the practical primacy of pacifism for the disciples of Christ. However, his discussion of possible exceptions qualifies the main line of his argument to such an extent that the latter loses most of its content. His practical imagination was shaped by established semi-national churches and by his native Switzerland. This disjunction between his central theological account and his practical reasoning helps explain why his thoughts on war have been used by proponents of radically different positions. What is lacking is a display of the sort of church life and practice this kind of thinking presupposes. This is true whether one emphasises the main pacifist argument or develops Barth's thought in the direction of the just war tradition.
\end{abstract}

World War I, especially Christian theological justification of war, militarism and nationalism, led Karl Barth to a radical theological rethinking. (For details of the following, see Rasmusson 2005a.) One can follow his reactions in his correspondence with Martin Rade and Wilhelm Herrmann. For months Barth's sermons dealt with the war. The first major results of his theological reconstruction - his commentary on Romans, which was published in two quite different editions - can in part be read as sustained attacks on the ideological support of the culture that caused this war - but also, especially in the second edition - on ideological support for revolutionary violence. In this regard, Bruce McCormack even talks about "an ethic of nonviolence" (McCormack 1995:282). Barth asked, for example:

What more radical action can [the revolutionary] perform than the action of turning back to the original root of "not doing" - and NOT be angry, NOT engage in an assault, NOT demolish? (Barth 1933:481)

Barth did not, however, espouse pacifism as a general ethical position (Barth 1933:471). A few years later, in 1925, he described militarism, together with völkisch nationalism and antiSemitism, as a confessional issue (Barth 1990:604-643).

In his ethics lectures of 1928, Barth provides his first longer and systematic discussion of war from a Christian ethical perspective (Barth 1981:143-146, 154-160). He discusses the new ideology of war. This new ideology is the consequence of modern total warfare and the idea of general conscription, which emphasises that, as members of a nation and citizens of a

1 Arne Rasmusson is Professor of Theology, Department of Historical, Philosophical and Religious Studies, Umeå University, Sweden, and research associate in the Faculty of Theology, Stellenbosch University,

South Africa. 
NGTT: Oopbron - http://ngtt.journals.ac.za

state we partake in its warfare even if we are not soldiers. Warfare no longer is the business of princes and the vocation of soldiers. Barth is of the opinion that the element of truth in this is that, if we belong to a people, we are also involved in its warfare - even if we have personally worked against its policies, even if we think our own country is in the wrong, or if we are conscientious objectors. It remains our people. However, Barth does criticise the way this ideology emphasises our fighting for our people, which tends to hide the fact that we are also killing the soldiers of another people. Barth does not think Christian ethics should condemn war in general, but it can help weaken modern military nationalism by concretely and realistically describing warfare as the killing of enemies "for coal and potash" (Barth 1981:159), thereby refusing to justify warfare ethically and spiritually. From this point of view, Barth can repeat his harsh criticism of the role played by theology during World War I:

Servility of this kind was what made the war theology of all countries in the last war such an abhorrent phenomenon. Ethically, the most dangerous form of participation in war is the chaplains' service (Barth 1981:158).

Barth does not think that ethics as such can either disallow or allow war. We should not as a general principle defend pacifism or conscientious objection, but neither should ethics be used for giving spiritual support for militarism. God commands respect for life, but we cannot control the concrete content of the command. We have to be open to the possibility of being commanded to go to war. Barth, however, also points to the opposite possibility. In his words,

... it may also be that as we listen more closely to what [God's command] demands of us, reason will be taken out of the ultimate reason and the resultant slogan will be: "Down with armaments" (Barth 1981:160).

In a similar way, Barth is verycautious about using revolution to overthrow the state, although this may be a last resort "in extreme and very rare circumstances"(Barth 1981:446).

NaziGermany's aggression and then WorldWarll prompted Barth to reflect further on warfare. In September 1938 he wrote a very famous letter to Czech theologian Josef Hromadka on "the Czech crisis" that had led to the Munich Agreement. The letter was published first in the Czech press, and then also in France, the Netherlands, Germany and Switzerland. In it Barth attacks the Western powers' appeasement policy with regard to Hitler's claim on Czechoslovakia and the bankruptcy of post war pacifism, and he calls the Czechs to resistance. Most well-known and controversial is the following sentence:

Jeder tschechische Soldat, der dann streitet und leidet, wird es auch für uns - und, ich sage es heute ohne Vorbehalt: er wird es auch für die Kirche Jesu Christitun, die in dem Dunstkreis der Hitler und Mussolini nur entweder der Lächerlichkeit oder der Ausrottung verfallen kann (Barth 2001:114. Cf. further 107-133). ${ }^{2}$

Barth was very widely, publicly and harshly criticised for this letter - especially in Germany, of course - also by his friends in Germany. The leader of the Confessing Church even wrote

2 "Every Czech soldier who then fights and suffers will do that for us as well - and, I say this today unreservedly: he will also do it for the church of Jesus Christ, that in the atmosphere of Hitler and Mussolini is bound to fall prey to either ridicule or extinction." 
NGTT Deel 54, Nommers $3 \& 4$, September en Desember 2013

a public letter of censure because of it. It led, further more, to the decision to ban Barth's publications in Germany. At the time Barth thought that, had the Western democracies resisted, Hitler would have backed down because Germany was not yet ready to go to war.

In December of that same year (1938), Barth defended his stand in a lecture that was published as The Church and the Political Problem of Our Day. In that lecture Barth said that sometimes the church had to be neutral or oppose the wars of one's own country. However, there were also times when the church had to support and call for armed defence. The Czech situation was such a situation, as would be any defence against continued German aggression. The reason was that Germany at that time represented "the dissolution of the just State". The church should support the defence of a just state "just as she would support a police measure taken in the normal way". Defending the just state would also indirectly be defending the cause of the church, as it cannot function in a totally unjust state such as Nazi Germany. Barth concluded:

[W] ould that the Church had concerned herself much more seriously with the restoration of the just State before matters had reached such a pass that she is concerned for its preservation in this form (Barth 1939:79).

And after the war broke out, Barth strongly defended it in similar language and also contrasted it with World War I: "[W]e approve it as a righteous war, which God does not simply allow, but which He commands us to wage" (Barth 1941a:4). In light of the German threat, pacifism had become unchristian and contributed to making the world defenceless (Barth 1944:21, 25).

Barth's most extensive and most systematic discussion of war as a Christian ethical question is in his Church Dogmatics (CD), in a volume originally published in 1951. This discussion is found in his ethics of creation as part of his discussion on the sixth commandment, "Thou shalt not kill" (CD III/4:450-470). As in his ethics lectures of 1928, he stresses that everyone is involved when a country wages war nowadays, that waging war primarily has to do with material interests, and that war is about killing as many of the enemy as possible. He sees it as perhaps hopeful that we have been forced "to face the reality of war without any optimistic illusions" (CD III/4:453). Any affirmation of the possibility that participation in warfare in certain circumstances may be commanded by God must, Barth says, "start with the assumption that the inflexible negative of pacifism has almost infinite arguments in its favour and is almost overpowering strong" (CD III/4:455).

Barth also takes up the issue of the radical shift in the Constantinian and post Constantinian church's understanding of violence and war, namely from aversion to the use of violence in the early church "to a no less self-evident affirmation of what had been previously thought impossible" (CD III/4:455). He seems to think that, on a theological level, this related to a "degeneration of ecclesiastical eschatology and the resultant overestimation and misinterpretation of the events and laws of the present world" (CD III/4:455). Even if Barth does not accept pacifism, he thinks the church has taken the "reality" of this world more seriously than the coming of the kingdom of God. "The criterion has thus been lost without the application of which there can be no controlling Christian will and action within this passing aeon" (CD III/4:456). War is seen as natural and even as part of the essence of the state. The history of nations, to a large extent, can be described as a history of war. This image, he says, needs to be demythologised. The church can never describe warfare as an essential part of the God willed order of the state. He goes even further and denies that "the exercise of force constitutes the essence of the state, i.e. its opus proprium"; instead, "it is an opus alienum for 
NGTT: Oopbron - http://ngtt.journals.ac.za

the state to have to exercise force" (CD III/4:456). ${ }^{3}$ Or, put positively, "[the state's] normal task is to fashion peace in such a way that life is served and war kept at bay" (CD III/4:458). Christian ethics can never give carte blanche to the use of warfare, but must try to make it only the ultima ratio.

Barth's discussion of this issue, as was said earlier, forms part of his creation ethics. However, he also refers to the use of force in his reflection on Christian discipleship and sanctification (CD IV/2:533-553, published in 1955). Considering the concrete form of Jesus' demand, Barth says:

It is common to every instance that the obedience concretely demanded of, and to be achieved by, the disciple, always means that he must move out of conformity with what he hitherto regarded as the self-evident action and abstention of Lord Everyman and into the place allotted to him, so that he is inevitably isolated in relation to those around him, not being able or willing to do in this place that which is generally demanded by the gods who are still fully respected in the world around. At this particular place the disciple is freed from the bonds of that which is generally done or not done, because and as he is bound now to Jesus (CD IV/2:546).

Although the disciple is freed from what is generally done, he/she is now not bound to an alternative general system of ethics, a new general law. Yet, Barth notes, the Gospels do point towards certain general lines of concrete obedience to Jesus. In discussing this, Barth also takes up the issue of force, saying that Jesus' command "takes the concrete form of an attestation of the kingdom of God as the end of the fixed idea of the necessity and beneficial value of force" (CD IV/2:549). Barth refers to several sayings in the Gospels that expressly state or imply that the disciples should not use force, and which "invalidate the whole friend foe relationship". These sayings are, according to Barth, based in the new reality of the kingdom that has come in Jesus Christ. Barth concludes that, although this should not be made into a general rule, the direction is clear and has to be carried out.

According to the sense of the New Testament we cannot be pacifists in principle, only in practice. But we have to consider very closely whether, if we are called to discipleship, we can avoid being practical pacifists, or fail to be so (CD IV/2:550).

George Hunsinger claims that this understanding of discipleship is grounded in Barth's Trinitarian understanding of the cross and the atonement. In the cross God meets the enemy with suffering love. "The politics of God thus reveals itself as the politics of nonviolent love" (Hunsinger 2000:35, cf. further 34-40). Christians are called to participate in God's life, which makes the cross the norm for Christian life.

According to Barth, it is only against the background of such a denial of the naturalness and necessity of war and a positive striving for peace that Christian ethics can also deny the absoluteness of pacifism. Even if war is not a necessity, neither can Christian ethics say that the possibility can be eliminated. A nation can, due to the behaviour of another nation, find itself in a situation where it has to face the possibility that "its very existence and autonomy" (CD III/4:461) is at stake. However, Barth does not think that even this automatically justifies war. What can make a war justifiable and even demanded by God is when the loss of independence will also lead to the loss of something that cannot be given up:

3 I have changed the translation of gewaltübung from "power" to "force." 
NGTT Deel 54, Nommers 3 \& 4, September en Desember 2013

It may well be that in and with the independence of a nation there is entrusted to its people something which, without any claim or pretension, they are commissioned to attest to others, and which they may not therefore surrender (CD III/4:462).

Barth even suggests that a people's relationship with God may be bound to its independence. He thus thinks that his own Switzerland, for example, should be defended (so also in Barth 1939:72-74). Likewise, a nation that is not itself under attack may be called to defend another nation that is.

On the issue of the responsibility of the individual, Barth says that every individual, as every Christian, is bound to the state; even, is the state. From this follows, on the one hand, that no one can leave all responsibility to the political authorities, but has to take responsibility him or herself. On the other hand, no one can discuss the issue of war as a private individual only, but has to take decisions as a citizen in solidarity with the state.

Barth defends the idea of general conscription, because it makes the question of warfare an issue that concerns the whole population. However, he also expects there to be situations where individuals, still in solidarity with their nations, will refuse to do military service. This presupposes that they do it as citizens, and not for their private conscience, and that they are ready to face the consequences of their refusal in the form of penalty and hostility. Christians must know that refusal to take part in a specific war may be what God commands. In this case too, Barth does not think that this should be a decision of the individual only. It should also be a church decision, and it should be taken with the specific case in mind (CD III/4:464-470; cf. Barth 1939:76-79). It can also never be an easy decision. In a different context, Barth expresses this hope:"May the Church show her inventiveness in the search for other solutions before she joins in the call for violence!" (Barth 1954:41).

His discussion of war in Church Dogmatics III was written primarily against the background of the aggression of Nazi Germany. Barth later found this problematic and saw it as a weakness (Barth 1971:81.) He thought the greatest flaw was his failure to deal with the changed situation created by the development of nuclear weapons. Nuclear war could never be justified, Barth claimed, and this made the just use of warfare even more unlikely (Barth 1971:83). The 1950s was characterised by an intense debate on nuclear weapons. Also at issue was whether Germany and Switzerland should develop their own. This was the only time, other than 1934, when Barth participated in a sort of confession regarding political issues. In April 1958, the Church Brotherhoods, which were a kind of continuation of the Confessing Church, presented ten theses to the Synod of the German Evangelical Church (reproduced in Yoder 2003:101103). These theses were anonymously written by Barth and stated that nuclear weapons, the use of which would mean the mutual annihilation of warring nations as well as of innocent neighbouring nations, had created a new situation in which the church could not be neutral. Not only the use, but also the preparation for nuclear warfare was a sin and no Christian could participate in either of those activities. According to the final thesis, "An opposite viewpoint or a neutral stance on this question is indefensible in Christian terms. Both would mean the denial of all three articles of Christian faith." The Synod did not accept these theses that, understandably, created much controversy, even among people associated with Barth during the church struggle. The year before Barth had already spoken out against nuclear weapons in response to similar appeals by Albert Schweitzer and by eighteen German nuclear physicists. This was occasioned by Bundeskanzler Konrad Adenauer's opinion that the German army should also have tactical nuclear weapons (Barth 1984:389-392). Barth also took part in a similar debate on possible Swiss nuclear armament (Barth 1984:398f.). 
NGTT: Oopbron - http://ngtt.journals.ac.za

Barth's position constitutes a remarkable break both with the Christian tradition in established churches generally and with twentieth century European theology in particular. Most of the theologians of his teachers' generation (such as Troeltsch, Herrmann, Harnack and Seeberg) and his own generation (such as Althaus and Hirsch) took the position that was also generally favoured in academic circles among historians and social and political scientists, namely that war simply is; it is a necessity, one of the foremost forces that create history, something that determines the role of peoples and nations. Thus it cannot be judged by ordinary ethical means. Even the doctrine of "just war" is impossible to accept. It would, for example, have made the recent unification of Germany illegitimate. ${ }^{4}$

Barth not only sharply criticised this idea of the naturalness and necessity of war; he also increasingly questioned the Christendom assumptions that most people had taken for granted (Rasmusson 2005b). In their description of reality, Christians should take the reality of the kingdom of God, as revealed in Jesus Christ, more seriously than so called realistic descriptions of the unavoidability of war. Moreover, united with Jesus Christ, the Christian is freed from what seems self-evident for "Lord Everyman". Christians see the world through different eyes and need not do what seems necessary from the perspective of others or those in power. Barth thus made a strong theological case for Christian pacifism as representing a general rule of discipleship. Although not an absolute principle, it is the normal path for the Christian church.

However, this represents only one side of Barth's discussion. He also said that every individual (including the Christian) was the state and as such had to act in close solidarity with and responsibility for the state and its people. Only in exceptional circumstances would the individual not do what, in a manner of speaking, was expected of Lord Everyman. When Barth described possible exceptions, he did it in a way that seems - contrary to his general argument - to make pacifist resistance an exception. His position was also so used in the debate about German rearmament and nuclear weapons in the 1950s and early 1960s, though Barth himself described this use of his argument as "sheer wickedness" (Barth 1971:82). It did go against the main thrust of his thinking, but the way he discussed the exceptions certainly left his argument open to such a line of interpretation. This becomes clear if one compares Barth's discussion of war with his reflections on abortion, euthanasia, suicide, the death penalty and homicide. He did say that any acceptance of the use of warfare mustincorporate a recognition that even in extremis it is far more difficult to express even a qualified affirmative at this point than when we stand on the outer margin in such matters as suicide, abortion, self-defence etc. (CD III/4:455).

This is, however, not the impression one gets when reading Barth's discussion of possible situations when warfare might be necessary.

David Haddorf describes Barth's position on war as"dialectical, open ended, and ... contextually linked to God's command in specific circumstances" (Haddorff 2010:386). But the section on war in Church Dogmatics is not explicitly related to specific circumstances, and Barth himself saw it as a problem that it was shaped too much by the situation of World War II, or maybe that he had not taken the new nuclear age seriously enough. One might more generally say that, in practice, Barth generalised one specific context, namely mid twentieth century Switzerland. Like most people he simply assumed the relative goodness and justness of his own nation. This was easy to do within the contexts of war since Switzerland had been living in peace

4 For Barth's direct discussion of this tradition, see $C D$ III/4:457f. 
NGTT Deel 54, Nommers 3 \& 4, September en Desember 2013

since the time of Napoleon. It was then, as now, unimaginable that it would aggressively attack its neighbours. Instead, it had at the time just experienced the unparalleled threat from Nazi Germany. Thus the experience of Switzerland goes well with Barth's theology of war and peace. But how should, say, British or American Christians read him? They (or most of them) also think that they represent relatively good and just societies that their nations are carriers of something that they are not allowed to abandon but are commanded to defend; and, in contrast to Switzerland, they see themselves as nations that have a responsibility towards the whole world. They intend to live up to this responsibility, even if it means the use of force - the same sort of responsibility Barth pleaded for during World War II. One should also remember that German theologians, such as Troeltsch and Herrmann, used exactly the same arguments to justify Germany's part in World War I as Barth used concerning Switzerland. In World War I, Germany was defending its specific culture and Germany's God given role in history. What would Barth have said if Switzerland had been invaded during that war? An invasion at that time would not have had the same post war consequences as an invasion by Nazi Germany.

In other respects as well, Barth's theological thinking reflects his Swiss context. He is not only a strong defender of universal conscription, but he also thinks that a general conscientious objection stance should not be legally recognised (as was the case in Switzerland at that time). There is no place in his political conception for, say, the so-called historic peace churches. Other churches should demand of the state that members of such churches should be punished for their refusing to do military service, both in times of peace and war. Barth does recognise that the introduction of universal conscription at the time of the French Revolution was closely connected to modern nationalism and that it led to the militarisation of European societies and to the emergence of the phenomenon of total war, which has resulted in what war historian John Keegan has called the "extraordinary, monstrous cultural aberration" World War I (Keegan 1993:21; cf. 347-366). However, another side to the argument seems more important to Barth: the close connection between universal conscription, citizenship and democracy, between arms bearing and equality. Again, every individual is the state. (Where does this leave women? At the time, Switzerland did not even have women's suffrage!) Every individual is responsible for the politics of his or her state. Barth seems to say that Christians - outside Switzerland - should have refused to do military service, most of the time, because most wars have been unjust. But when you have a system of universal military conscription, strongly defended by a church that also thinks that military service is compulsory for its members, then it is difficult to contemplate that refusal to serve is anything other than the exception. There are almost no historic examples of such selective refusal. The most clear cut case for refusing to serve was in Germany during World War II. In 1939, Barth actually made some attempts to call upon Christians in Germany to refuse to serve in the German army, to become involved in sabotage and boycotts instead. He found no support for this among his theological friends in the Confessing Church. Of course, refusing military service in Germany would have meant death (some were executed for this very reason), fleeing the country or going underground. But many also thought it wrong to refuse military service for Christian ethical reasons. Therefore, Barth thought this attempt to call Germans to refuse doing military service was pointless, and he did not write publicly about it (Busch 1996:346; Gollwitzer 1962:337-342).

Also reflecting his Swiss tradition of an armed male population keeping their weapons with them at home is Barth's criticism of "the institution of standing armies" (CDIII/4:460). Because of modern arms technology, this was a rather unrealistic expectation and one 
NGTT: Oopbron - http://ngtt.journals.ac.za

cannot be sure what Barth meant by it. However, David Clough suggests that taking Barth's position seriously would mean that "there is no mandate to prepare for war"even if one has to be ready for that very rare occasion when God will call Christians to war (Clough 2005:98). To prepare for war might be compared to a situation where the state and the church support a system of euthanasia and suicide clinics, although euthanasia should be an extreme exception. The difference is, of course, that any effective military defence requires large scale preparation. In a critical discussion of the Cold War Barth writes: "I must admit that if I were an American or British statesman I would not neglect preparations for a possible military defence" (Barth 1951). In 1938 he called on Western powers to stand up against Germany's aggression against Czechoslovakia. To do this, long and large scale preparations for war would have been needed. One problem was that, in the period between World Wars I and II, England was much more antimilitaristic than Germany and, therefore, could not arm itself quickly enough. Barth accuses interwar pacifism for contributing to this situation. But is it not likely that a hypothetical English church dominated by Barthian theology would have supported such anti-war sentiments?

Given Barth's historical description of the role of warfare in history, World War II is an exceptional case. He could even write, during the war, that this war had "a totally different character (Barth 1941b:32). However, it stills functions as the primary implicit background for his general reflection on war as an ethical issue. This creates severe tensions in his account. Oliver O'Donovan, on the other hand, thinks that Barth's continuing espousal of his very critical view of the historical role of warfare shows that Barth did not learn anything from World War II precisely because he saw it as an exception (O'Donovan 2004:264). Critics may say that one has to prepare for the worst possible scenario even if it is unlikely. Compared to Europe, the USA used to be antimilitaristic, but now its policy is one of absolute military superiority. However, it is hard to imagine that anyone would dispute Barth's overall description of the history of war up to 1950. O'Donovan's own discussion of the just war tradition, although using historical material, clearly assumes the post1945 situation and takes for granted that the type of situation that World War II exemplifies is normal rather than abnormal (O'Donovan 2003).

Some would say that these tensions show that Barth's theological account is inadequate or one sided, others that he did not truly draw out the consequences of his theological account. O'Donovan claims that Barth's position creates a disjunction between actual politics and the gospel, and that it would be better if he had a fully developed just war account. He thinks that Barth was sceptical of the language of just war (see Barth 1971:82) because it seems to make war seem normal. Yet, not to reflect deeply on such issues and on what preparing for a just war could lead to more indiscriminate and disproportionate use of force in a situation of war than a Christian should accept (O'Donovan 2004:246-275). However, one might also say-as John Howard Yoder does - that Barth's concrete discussions of Nazi Germany, nuclear pacifism and revolutionary violence (in practice, if not in words) were informed by just war thinking (Yoder 2003:119f.). In the 1950s, when he was discussing the possible overthrow of governments, he proposed three relative criteria that are typical of the just war tradition. The first is that the government should have reached a state of such intolerable injustice and inhumanity that it cannot be a state anymore. Second that all other means should have been exhausted. Third, that war would offer "a real opportunity to better the situation". Barth thought that most revolutions had failed on the third criterion, if not already on the other two (Barth 1963:76f.). However, in his discussion of war in Church Dogmatics Barth seems to deny this third criterion when he writes that if the command of God should 
NGTT Deel 54, Nommers $3 \& 4$, September en Desember 2013

require a nation - say Switzerland - to defend itself, this command should be understood as "quite unconditional", as independent of the prospects of success (CDIII/4:463). The people should, therefore, fight to the end (whatever that is), even if they think that the outcome will be the same; except that many more people will be killed and much more destruction will follow - probably including a worsening of whatever conditions prompted the defence to start with. So it was presumably wrong, say, for Denmark in 1940 to more or less surrender without fighting. Criticising pacifist absolutism Barth ends up with absolutism. Yoder comments:

It is hard to see how, after starting with such realism as his position demanded at the outset, Barth could ever come to say in effect that precisely those countries which have the least chance of being able to defend themselves effectively, the small Western democracies, are the ones for whom war is most likely to be a commanded thing (Yoder 2003:68).

However, maybe Barth wanted to say that, if they had been specifically commanded by God to fight, they should do so without reflecting on the likelihood of success. Understood in this way, new and difficult questions arise about Barth's general understanding of God's command which I cannot deal with here (cf. McKenny 2010).

On the other hand, Hunsinger (like Yoder 2003 and Clough 2005), thinks that Barth's "equivocal relation to pacifism stands in contradiction to the thrust of his theology"(Hunsinger 2000:119). Although Barth displays little knowledge of the main tradition of Christian pacifism, often caricaturing it, his core theological argument is close to that tradition. It is, Yoder writes, "nearer in fact than that of any really prominent theologian in the history of European Protestant dogmatics" (Yoder 2003:10f. cf. 3638). It is also consistent with his overall theology. Still, one might well argue that Barth's discussion of possible exceptions qualifies the main line of his argument to such an extent that the latter loses most of its content. His practical imagination was shaped by established semi national churches and his native Switzerland. This disjunction between his central theological account and his practical reasoning helps explain why his thoughts of war have been used by radically different positions; in his own time in ways he himself thought perverse (for example, in the debates on German rearmament, the Cold War and communism, and nuclear weapons), and later on in debates on the use of revolutionary violence. What is lacking is a display of the sort of church life and practices this kind of thinking presupposes. This is true whether one emphasises the main pacifist argument or develops Barth's thought in the direction of the just war tradition (cf. Bell 2009).

\section{BIBLIOGRAPHY}

Barth, K. 1933. The Epistle to the Romans. London: Oxford University Press.

Barth, K. 1939. The Church and the Political Problem of Our Day. New York, NY: Scribner. Barth, K. 1941a. A Letter to Great Britain from Switzerland. London: Sheldon.

Barth, K. 1941 b. First Letter to the French Protestants. In A Letter to Great Britain from Switzerland. London: Sheldon.

Barth, K. 1944. The Church and the War. New York, NY: Macmillan.

Barth, K. 1951. Nazism and Communism. Christianity and Crisis (Feb. 27). Online at: http://www.religiononline.org/showarticle.asp?title=400. [2011, February 21]. Barth, K. 1954. Against the Stream: Shorter Post War Writings, 194-652. New York, NY: Philosophical Library.

Barth, K. 1958. Church Dogmatics IV/2. Edinburgh: T\&T Clark. Barth, K. 1961. Church Dogmatics III/4. Edinburgh: T\&T Clark. Barth, K. 1971. Fragments Grave and Gay. London: Collins. 
NGTT: Oopbron - http://ngtt.journals.ac.za

Barth, K. 1981. Ethics. New York, NY: Seabury.

Barth, K. 1984. Offene Briefe 1945-1968. Zürich: Theologischer Verlag.

Barth, K. 1990. Vorträge und kleinere Arbeiten 1922-1925. Zürich: Theologischer Verlag. Barth, K. 2001. Offene Briefe 1935-1942. Zürich: Theologischer Verlag.

Barth, K. 1963. Table Talk. Edinburgh: Oliver and Boyd.

Bell, D. M. 2009. Just War as Christian Discipleship: Recentering the Tradition in the Church Rather Than the State. Grand Rapids, MI: Brazos.

Busch, E. 1996. Unter dem Bogen des einen Bundes: Karl Barth und die Juden 1933-1945.

NeukirchenVluyn: Neukirchener.

Clough, D. 2005. Ethics in Crisis: Interpreting Barth's Ethics. Aldershot: Ashgate. Gollwitzer, H. 1962.

Forderungen der Freiheit: Aufsätze und Reden zur politischen Ethik. München: C. Kaiser.

Haddorff, D. W. 2010. Christian Ethics as Witness: Barth's Ethics for a World at Risk. Eugene, OR: Cascade.

Hunsinger, G. 2000. Disruptive Grace: Studies in the Theology of Karl Barth. Grand Rapids, MI: Eerdmans.

Keegan, J. 1993. A History of Warfare. New York, NY: Alfred A. Knopf.

McCormack, B. L. 1995. Karl Barth's Critically Realistic Dialectical Theology: Its Genesis and Development 1909-1936. Oxford: Clarendon.

McKenny, G.P. 2010. The Analogy of Grace: Karl Barth's Moral Theology. Oxford: Oxford University Press.

O'Donovan, O. 2003. The Just War Revisited. Cambridge: Cambridge University Press. O'Donovan, O. and O'Donovan, J. L. 2004. Bonds of Imperfection: Christian Politics, Past and Present. Grand Rapids, MI: Eerdmans.

Rasmusson, A. 2005a. Church and Nation-state: Karl Barth and German Public Theology in the Early 20th Century. NGTT (46), 511-524.

Rasmusson, A. 2005b. The Politics of Diaspora: The Post Christendom Theologies of Karl Barth and John Howard Yoder. In Jones, L. G., Hütter, R. and Velloso Ewell, R. (eds.), God, Truth, and Witness: Engaging Stanley Hauerwas. Grand Rapids, MI: Brazos.

Yoder, J. H. 2003. Karl Barth and the Problem of War and Other Essays on Barth.

Eugene, OR: Cascade.

\section{KEY WORDS}

Karl Barth

Church

War

Pacifism

Just war

\section{TREFWOORDE}

Karl Barth

Kerk

Oorlog

Passivisme

Geregverdigde oorlog

Contact Details/Kontakbesonderhede

Prof Arne Rasmusson

Umeå University

SE-901 87 Umeå

Sweden

E-mail: arne.rasmusson@religion.umu.se 